\title{
Contact-Mediated Loss of the Nonsynaptic Response to Transmitter During Reinnervation of an Identified Leech Neuron in Culture
}

\author{
Pierre Drapeau, Elizabeth Melinyshyn, and Sergio Sanchez-Armass ${ }^{a}$ \\ McGill University Centre for Research in Neuroscience and Department of Neurology, Montreal General Hospital, \\ Montreal, Quebec, Canada H3G 1 A4
}

\begin{abstract}
We have examined the modification of responses to transmitter during the reformation of a specific synapse by identified leech neurons in culture. Single pressure-sensitive mechanosensory (P) neurons in culture and the soma of this cell in vivo have 2 conductances that are activated by application of 5-HT: a Cl conductance and a monovalent cation conductance ( $g$ Cation $_{\mathrm{s}}$ ); synaptic release of $5-\mathrm{HT}$ by a serotoninergic Retzius cell in vivo and in culture activates only the $\mathrm{Cl}$ conductance and not $g$ Cation $_{s}$ in the $P$ cell. We have characterized the loss of $g$ Cation $_{s}$ in $P$ cells by manipulating the culture conditions.

When 5-HT was applied from a pipette, innervated $P$ cells and $P$ cells paired with Retzius cells that had not formed synapses had a $g$ Cation $_{\mathrm{s}}$ that was markedly reduced com-

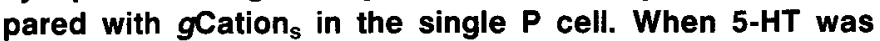
included in the culture medium in which single $\mathbf{P}$ cells were grown, $g$ Cation $_{\mathbf{s}}$ was not reduced. When Retzius-P cell pairs were treated with reserpine, which was shown to deplete

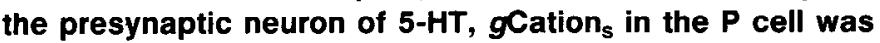
as low as in untreated pairs. Pairing aldehyde-fixed Retzius cells with untreated $P$ cells also resulted in the loss of gCation $_{\mathrm{s}}$. The Retzius cell had both types of receptors, but synapse formation did not affect $g$ Cation ${ }_{s}$ in the presynaptic neuron.
\end{abstract}

The results demonstrate that the loss of the nonsynaptic response of the $P$ cell to transmitter is due to contact between the neurons rather than to the release of transmitter or trophic factors. We suggest that contact-mediated loss of counter-effective receptors may be a prelude to synapse formation.

In contrast to the wealth of information about the changes in properties (Katz and Miledi, 1972; Neher and Sakmann, 1976) distribution (Fambrough, 1979), and structure (Mishina et al., 1986) of ACh receptors in muscle cells, little is known about

\footnotetext{
Received Oct. 13, 1988; revised Dec. 12, 1988; accepted Dec. 16, 1988.

We thank Mr. J.-M. Clairoux for his expert technical assistance, Dr. A. C. Cuello for his generous gift of the monoclonal antibody to 5-HT, Ms. K. L. Teff for performing the 5-HT assays, and Prof. M. Cohen for his discussions and criticism of the manuscript. S.S.-A. was supported as a Visiting Scientist by the FCAR and the MRC of Canada and the Research Institute of the Montreal General Hospital. P. D. was supported by grants and Scholarships from the FRSQ and the MRC of Canada.

Correspondence should be addressed to Dr. Pierre Drapeau, McGill University Centre for Research in Neuroscience and Department of Neurology, Montreal General Hospital, 1650 Cedar Avenue, Montreal, Quebec, Canada H3G 1A4.

a Present address: Department of Physiology, University of San Luis Potosi, San Luis Potosi, Mexico.

Copyright (C) 1989 Society for Neuroscience $0270-6474 / 89 / 072502-07 \$ 02.00 / 0$
}

changes in neuronal receptor properties during synapse formation. Some receptors appear and others disappear at different developmental stages in grasshopper (Goodman and Spitzer, 1979) and Xenopus neurons (Bixby and Spitzer, 1982). It is known from studies of the well-characterized cells of invertebrates that mature neurons can have multiple subtypes of receptors for the same transmitter (Gerschenfeld, 1973), yet often only a single subtype may be present at some postsynaptic sites (Gerschenfeld and Paupardin-Tritsch, 1974). For example, application of 5-HT to the soma (devoid of serotoninergic synapses) of a pressure-sensitive mechanosensory $(P)$ neuron of the lccch clicits a biphasic response: depolarization followed by a desensitizing Cl-dependent hyperpolarization(Henderson, 1983). When $5-\mathrm{HT}$ is released synaptically by a Retzius cell only $\mathrm{Cl}$ dependent postsynaptic potentials are observed (Fuchs et al., 1982).

How the selection of receptor subtypes comes about during the development of the nervous system is unknown. In order to circumvent many of the problems associated with studying synaptogenesis in vivo, identified leech neurons have been removed and grown in tissue culture, where they reform specific synapses when paired with appropriate partners (Ready and Nicholls, 1979). Retzius cells from the leech reinnervate P cells in culture as shown by biochemical, morphological, and electrophysiological criteria (Nicholls, 1987). We have demonstrated (Drapeau and Sanchez-Armass, 1988) that the $P$ cell in culture has 2 conductances activated by $5-\mathrm{HT}$ : a $\mathrm{Cl}$ conductance $\left(g \mathrm{Cl}_{\mathrm{S}}\right)$ and a nonselective monovalent cation conductance $\left(g\right.$ Cation ${ }_{\mathrm{S}}$ ); only $g \mathrm{Cl}_{\mathrm{S}}$ is activated when $5-\mathrm{HT}$ is released synaptically by a Retzius cell. These observations show that reinnervation of the $P$ cell in culture mimics precisely the situation in situ, i.e., to the level of choosing the correct 5-HT receptor subtype.

We have examined the ionic conductances activated by $5-\mathrm{HT}$ application onto single and paired Retzius and $P$ cells in culture in order to determine the effects of synapse formation on the responses to 5-HT in these neurons. By modifying the conditions under which the neurons were grown, we observed that gCation $_{\mathrm{S}}$ (the nonsynaptic response to 5-HT) was reduced selectively in the target cell in a process that depended on contact between the neurons. Brief reports of these results have appeared elsewhere (Drapeau and Sanchez-Armass, 1987; Sanchez-Armass and Drapeau, 1988).

\section{Materials and Methods}

Cultures. Retzius and P cells were isolated from the nervous system of the leech Hirudo medicinalis (purchased from Ricarimpex, Audenge, France) and cultured as described previously (Dietzel et al., 1986). De- 
sheathed ganglia were exposed to collagenase (Type XI, Sigma) and the somas of the easily identified Retzius and $P$ neurons were removed by aspiration into a micropipette. The cells were plated singly or in pairs in the wells of polylysine-coated microtest culture dishes containing Leibovitz-15 medium (L-15) supplemented with $2 \%$ heat-inactivated fetal bovine serum (FBS; Gibco Canada, Burlington, Ontario). Under these conditions, the cells usually did not extend neurites (better for voltage clamping; see Dietzel et al., 1986; Drapeau and Sanchez-Armass, 1988 ) and formed synapses after Retzius and P cell somas were juxtaposed during plating. Most experiments were performed $7-10 \mathrm{~d}$ following plating.

In some experiments, 5-HT (100 $\mu \mathrm{M})$ or reserpine (1 $\mu_{\mathrm{M}}$ diluted from a $500 \mu \mathrm{m}$ stock solution dissolved in methanol) were added to the culture media for the 7-10 d incubation period. The stability of 5-HT in the supplemented culture media throughout the incubation period was ascertained by reverse-phase HPLC fluorometry as described previously (Anderson et al., 1987). The effectiveness of the reserpine treatment in depleting the Retzius cells of 5-HT was determined by immunocytochemical staining of control and reserpine-treated cells using a monoclonal antibody specific for aldehyde-modified 5-HT (Consolazione et al., 1981) (gift of Dr. A. C. Cuello). We have used this monoclonal antibody previously to localize 5-HT in fixed Retzius cells in culture at the electron microscopic level (Kuffler et al., 1987). Cells were washed with $0.165 \mathrm{~m}$ PBS and were fixed for $15 \mathrm{~min}$ in PBS containing $4 \%$ paraformaldehyde. The cells were permeabilized by rinsing with PBS containing $0.1 \%$ of the detergent Triton X-100 and treated for $1 \mathrm{hr}$ with the monoclonal antibody dissolved in the same solution. The dishes were then rinsed with $0.1 \%$ Triton/PBS and a secondary antibody (goat anti-rat IgG conjugated to fluorescein isothiocyanate; Sigma) dissolved in the same solution was added for $1 \mathrm{hr}$. The dishes were rinsed with detergent-free PBS and a glycerol-ethylene diamine mounting solution was added. The cells were photographed using a I eitz. fluorescence microscope.

In one series of experiments, Retzius cells were fixed for $30 \mathrm{~min}$ in $0.4 \%$ (wt/vol) paraformaldehyde $/ 0.6 \%$ glutaraldehyde dissolved in PBS or in 10-, 30-, or 100-fold dilutions of this fixative. The fixed Retzius cells were transferred at 10 min intervals into 3 (serial) droplets of L-15 in order to remove the aldehydes before being paired with untreated $P$ cells in culture as described above.

Recordings. Action potentials were evoked in cultured Retzius cells by passing current through the recording microelectrode using a bridge circuit. Retzius and $P$ cells in culture were voltage-clamped with a single microelectrode ( $4 \mathrm{M}$ Cs acetate) using a sample-and-hold amplifier (Axoclamp 2a, Axon Instruments, Burlingame, CA) and were superfused continuously, as described previously (Drapeau and Sanchez-Armass, 1988a). The solutions used are named as follows (concentrations in mM): normal solution: $\mathrm{NaCl}, 165 ; \mathrm{KCl}, 5 ; \mathrm{MgCl}_{2}, 1 ; \mathrm{CaCl}_{2}, 10$; glucose, 10; HEPES, 10; TrisCl solution: TrisCl, $165 ; \mathrm{CsCl}, 5 ; \mathrm{MgCl}_{2}, 2 ; 3,4-$ diaminopyridine (DAP), 10; glucose, $10 ; \mathrm{Na}+\mathrm{KSO}_{4}$ solution: $\mathrm{Na}_{2} \mathrm{SO}_{4}$, $130 ; \mathrm{K}_{2} \mathrm{SO}_{4}, 4 ; \mathrm{MgSO}_{4}, 5$; DAP, 10 ; glucose, 10; 9-anthracenecarboxylic acid (9-AC), $0.1 \mathrm{~mm}$ from a $0.1 \mathrm{~m}$ stock solution dissolved in methanol; HEPES, 10. Other solutions in which one ingredient was excluded (DAP), substituted $(\mathrm{Ca}$ or $\mathrm{Mg}$ ), or added $[0.1 \% \mathrm{vol} / \mathrm{vol}$ of $0.1 \mathrm{M}$ stock solutions of cyproheptadine (CYP), or 4-stilbeneisothiocyanato-2,2'-disulfonic acid (SITS) dissolved in methanol] are indicated in the text and figure legends. 5 -HT was applied by pressure ejection $(200 \mathrm{msec}$ pulses at $1 \mathrm{bar})$ from a large-diameter $(15-20 \mu \mathrm{m})$ pipette containing $100 \mu \mathrm{M}$ 5-HT dissolved in the same solution used to superfuse the cells. This concentration of 5-HT gave reproducible maximal responses, although the 5-HT concentration at the cell must have been lower than in the pipette.

\section{Results}

\section{5-HT-activated currents in single Retzius and $P$ cells}

Application of 5-HT depolarizes both the P cell (Henderson, 1983) and Retzius cell (Erwin and Theis, 1975) and in addition induces a slower, Cl-dependent hyperpolarization of both neurons in situ (Walker and Smith, 1973; Henderson, 1983). The results shown in Figures 1 and 2 demonstrate that both the single Retzius cell and $\mathrm{P}$ cell in culture had a $g \mathrm{Cl}_{\mathrm{s}}$ and $\mathrm{g} \mathrm{Cation}_{\mathrm{s}}$, as shown previously for the P cell (Drapeau and Sanchez-Armass, 1988).

$\mathrm{gCl}_{S}$. Figure $1, A$ and $D$, shows current recordings from a single $P$ cell and a single Retzius cell, respectively, that were voltage-clamped and superfused with TrisCl solution (impermeant cations: $\mathrm{Na}$ replaced by Tris, $\mathrm{K}$ by $\mathrm{Cs}, \mathrm{Ca}$ by $\mathrm{Mg}$ ) in order to isolate $\mathrm{gCl}_{\mathrm{s}}$. The currents were outward at depolarized potentials and reversed near the resting potentials of these cells $(-50 \mathrm{mV}$; Fuchs et al., 1981), as seen in the plots of peak $I$ versus $V$ in Figure $1, C$ and $F$ (open circles). The $I-V$ relationships showed slight outward rectification. The average values $\pm \mathrm{SEM}$ of $\mathrm{gCl}_{\mathrm{S}}$ (chord conductance at $-20 \mathrm{mV}$ ) were $43.0 \pm$ $5.7 \mathrm{nS}(n=15)$ and $19.3 \pm 4.1 \mathrm{nS}(n=7)$ for the Retzius and $\mathrm{P}$ cell, respectively. $g \mathrm{Cl}_{\mathrm{S}}$ underlies the $\mathrm{P}$ cell response to synaptic release of 5-HT by the Retzius cell when the neurons are paired in culture (Drapeau and Sanchez-Armass, 1988) and in vivo (Fuchs et al., 1982).

In order to determine the specificity of the 5-HT-activated conductance, the Retzius cell was tested as shown in Figure 2. The traces in Figure $2 A$ show that the response to pipette application of 5-HT of a single Retzius cell superfused with TrisCl solution was blocked reversibly by a high concentration of CYP, a 5-HT antagonist in the leech (Sawada and Coggeshall, 1976), and by the $\mathrm{Cl}$ channel blockers 9-AC (Bryant and MoralesAguilera, 1971) and SITS (Knauf and Rothstein, 1971). Similar results with CYP, 9-AC, and SITS have been reported previously for $\mathrm{gCl}_{\mathrm{S}}$ in the single $\mathrm{P}$ cell in culture (Drapeau and Sanchez-Armass, 1988).

gCation $_{s}$. Figure 1, B and E, shows currents recorded in single $P$ cells and Retzius cells, respectively, superfused with $\mathrm{Na}+\mathrm{K}$ $\mathrm{SO}_{4}$ solution $\left(\mathrm{Cl}\right.$ substituted with impermeant $\mathrm{SO}_{4}$ ) in order to isolate gCation $_{\mathrm{S}}$ (see Drapeau and Sanchez-Armass, 1988). The current activated by application of 5-HT was inward at hyperpolarized potentials and reversed at $14.7 \pm 4.4 \mathrm{mV}(n=7)$ for the Retzius cell and at $5.3 \pm 2.9 \mathrm{mV}(n=9)$ for the P cell (filled circles, Fig. 1, $C, F$ ). As shown previously for the $\mathrm{P}$ cell (Drapeau and Sanchez-Armass, 1988), gCation in $_{S}$ the Retzius cell did not require divalent cations, and omission of the $\mathrm{K}$ channel blocker DAP from the $\mathrm{Na}+\mathrm{K} \mathrm{SO}_{4}$ solution had no effect on the 5-HT-dependent current recorded (not shown). Assuming identical $\mathrm{Na}$ and $\mathrm{K}$ gradients for both cells, the more positive reversal potential for the Retzius cell response would suggest that $g$ Cation is more selective for $\mathrm{Na}$ in this cell compared with the $\mathrm{P}$ cell. gCation $_{\mathrm{S}}$ was $9.6 \pm 1.4 \mathrm{nS}(n=13)$ and $11.5 \pm 1.5 \mathrm{nS}(n=16)$ for the Retzius and $\mathrm{P}$ cell, respectively, and was lower than $\mathrm{gCl}_{\mathrm{S}}$ in both cells. CYP (but not 9-AC) also blocked gCation , as shown in Figure $2 \mathrm{~B}$ for a Retzius cell in $\mathrm{Na}+\mathrm{K} \mathrm{SO}_{4}$ solution and shown previously for the $\mathrm{P}$ cell (Drapeau and SanchezArmass, 1988).

\section{Responses of innervated cells to 5-HT}

$\mathrm{gCl}_{s}$. Synaptic release of 5-HT upon firing of an action potential in a Retzius cell was shown to activate $g \mathrm{Cl}_{\mathrm{s}}$ (Figs. $3 A, 4 A$ ) but not $g$ Cation $_{s}$ in the P cell (Drapeau and Sanchez-Armass, 1988). The upper traces of the pairs of recordings in Figure $3 B$ show that when 5-HT was applied from a pipette both synaptic partners had a $\mathrm{gCl}_{\mathrm{S}}$ that was lower than that observed with single cells. $g \mathrm{Cl}_{\mathrm{S}}$ was $8.0 \pm 2.7 \mathrm{nS}(n=9)$ for paired P cells and was $19.3 \pm 4.1 \mathrm{nS}(n=7)$ for the single P cell (see Fig. 4$)$. These results are consistent with the conclusion that $g \mathrm{Cl}_{\mathrm{S}}$ is clustered at postsynaptic sites and that there is a synaptic diffusional barrier to applied 5-HT (Drapeau and Sanchez-Armass, 1988). For Retzius cells, $g \mathrm{Cl}_{\mathrm{s}}$ was $11.0 \pm 2.5 \mathrm{nS}(n=9)$ for the paired cell and $43.0 \pm 5.7 \mathrm{nS}(n=15)$ for the single cell.

$\mathrm{gCation}_{\mathrm{S}} . \mathrm{gCation}_{\mathrm{s}}$ in innervated $\mathrm{P}$ cells was not activated by 


\section{$P$ cell}
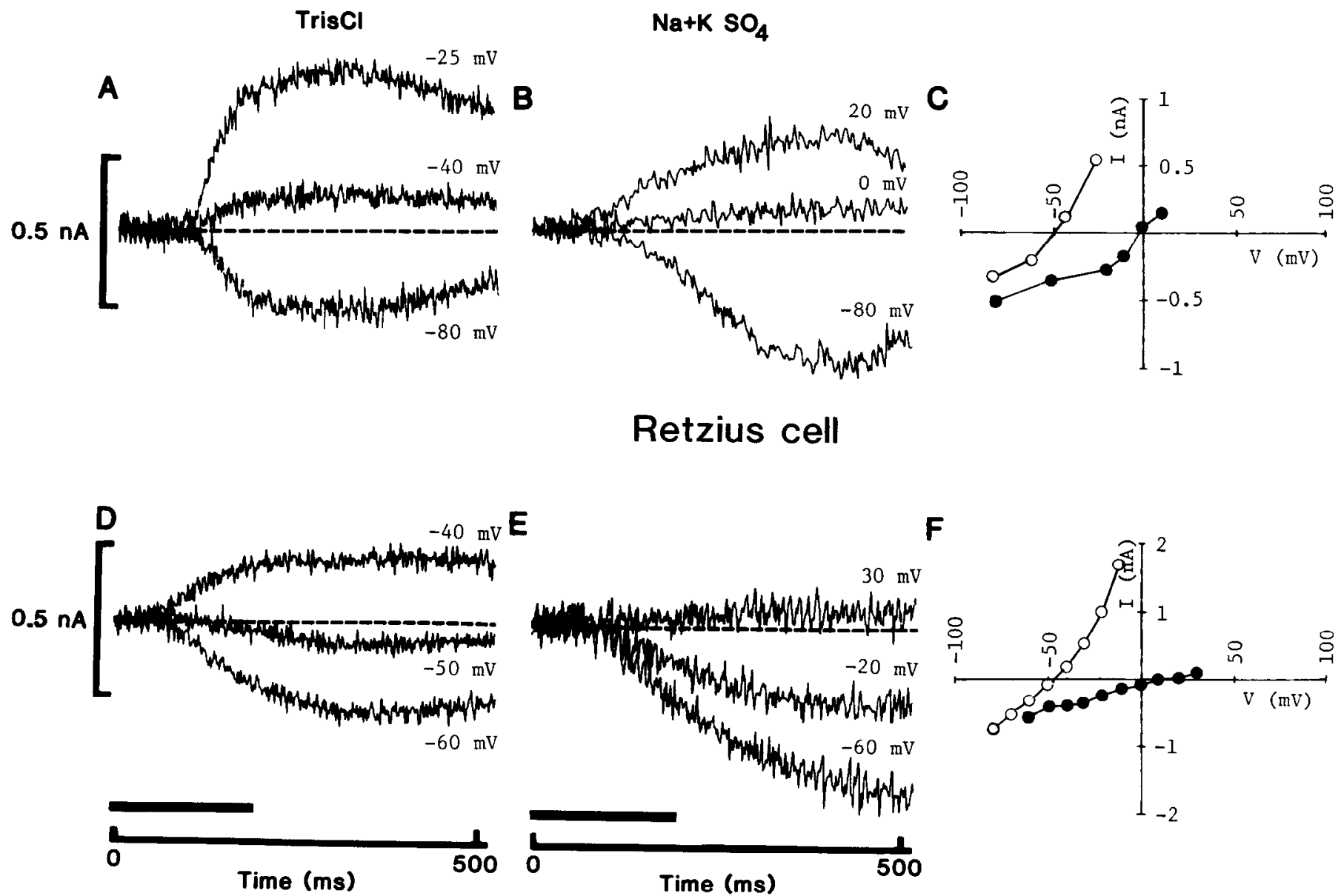

Figure 1. $I-V$ relationships for $g \mathrm{Cl}_{\mathrm{s}}$ and $g$ Cation ${ }_{\mathrm{s}}$ in the cultured $\mathrm{P}$ cell and the Retzius cell. $A-C$, Data for $\mathrm{P}$ cell; $D-F$, data for Retzius cell. The cells in $A$ and $D$ were superfused with TrisCl solution and 5-HT was applied from a pipette during the first $200 \mathrm{msec}$ of the recordings (as indicated by the dark bars) obtained at the indicated holding potentials. The peak $I-V$ relationships are plotted as the open circles in $C$ and $F$. The cells in $B$ and $E$ were superfused in $\mathrm{Na}+\mathrm{K} \mathrm{SO}_{4}$ solution and 5-HT was applied as described above. The peak $I-V$ relationships are plotted as the filled circles in $C$ and $F$. The current traces were superimposed at the beginning of the recordings, and the baselines are indicated by the broken lines.

synaptic release of 5-HT as determined by the similarity of the reversal potcntials for the postsynaptic current and $\mathrm{gCl}_{\mathrm{S}}$ or by complete block of the synaptic response by $9-\mathrm{AC}$ (Fig. $4 B$ and Drapeau and Sanchez-Armass, 1988a). The lower traces of the pairs of recordings in Figure $3 B$ show that when 5-HT was

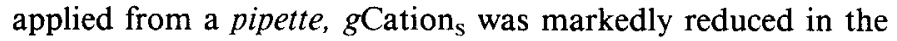
$P$ cell following synapse formation $(2.5 \pm 0.6 \mathrm{nS}, n=11$, for paired $P$ cell compared with $11.5 \pm 1.5 \mathrm{nS}, n=16$ for single $\mathrm{P}$ cell-see Figs $1 B$ and $4 B$ ). In contrast to the results with the $\mathrm{P}$ cell, $\mathrm{gCation}_{\mathrm{S}}$ in the Retzius cell was not reduced following synapse formation $(12.0 \pm 3.7 \mathrm{nS}, n=7$, for the paired Retzius cell compared with $9.6 \pm 1.4 \mathrm{nS}, n=13$, for the single Retzius cell; see Fig. 1E).

\section{Effects of pairing without innervation}

We examined whether the changes in conductances observed in the target $P$ cell required the formation of a synapse. To do this, innervated $\mathrm{P}$ cells were compared with $\mathrm{P}$ cells paired with a Retzius cell that had not formed synapses, i.e., uninnervated $\mathrm{P}$ cells. $g \mathrm{Cl}_{\mathrm{S}}$ and $g$ Cation ${ }_{\mathrm{S}}$ were determined for the P cells and the rcsults are plotted in Figure 4.

As shown in Figure $4 A$, pipette application of 5-HT onto uninnervated $\mathrm{P}$ cells elicited a $g \mathrm{Cl}_{\mathrm{S}}$ that was not significantly lower than observed in single $\mathrm{P}$ cells. In contrast to the results with $\mathrm{gCl}_{\mathrm{s}}, g$ Cation $_{\mathrm{s}}$ in uninnervated P cells was completely absent in one-third (7/20) and was markedly reduced in the rest of the P cells tested (pooled data plotted as upper stippled bar, Fig. $4 B$ ). This suggests that the reduction of postsynaptic gCation preceded synapse formation.

\section{Effects of 5-HT}

We examined whether the secretion of transmitter, even in the absence of detectable synaptic release, was necessary for the postsynaptic reduction of gCation $_{\mathrm{s}}$. Single $\mathrm{P}$ cells were incubated in the presence of $100 \mu \mathrm{M} \mathrm{5-HT}$ (present throughout the 7-10 d incubation period - see Materials and Methods), and the results of the conductance measurements are plotted as the lower open bars in Figure 4. Chronic incubation in the presence of 
A TrisCl

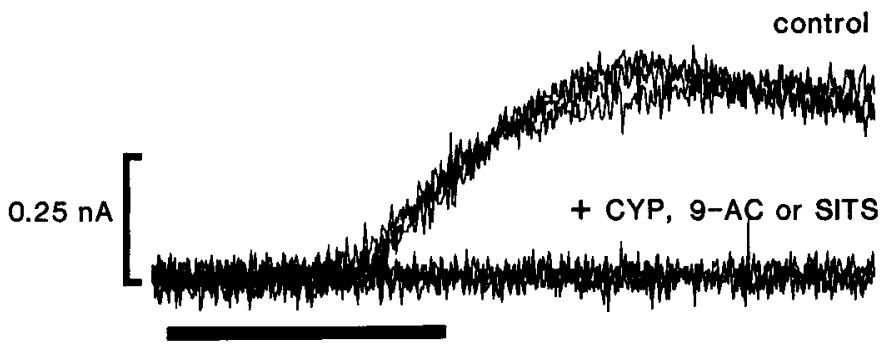

B $\quad \mathrm{Na}+\mathrm{K} \mathrm{SO}_{4}$

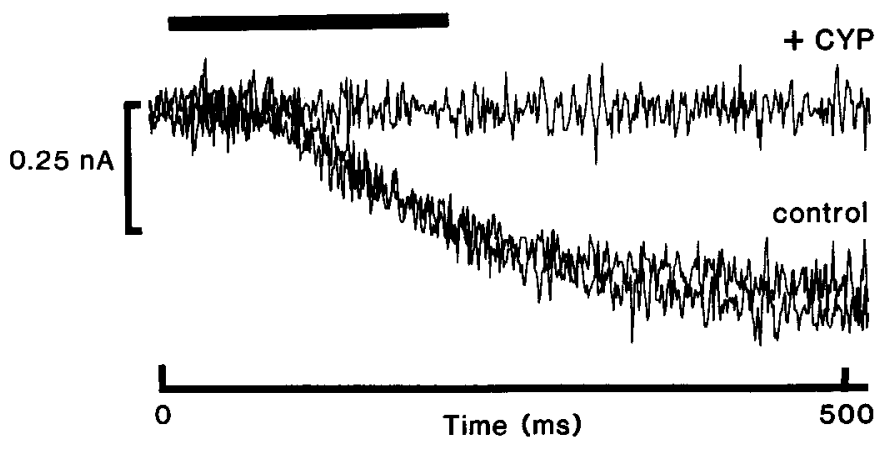

Figure 2. Effects of blockers on $g_{\mathrm{Cl}}$ and $g$ Cation $\mathrm{s}_{\mathrm{s}}$ in the cultured Retzius cell. $A$, Retzius cell was voltage-clamped at $-20 \mathrm{mV}$ and superfused in TrisCl solution. 5-HT was applied from a pipette for the first $200 \mathrm{msec}$ of the recording. The superfusion solution was changed to one containing either $100 \mu \mathrm{M}$ CYP, 9-AC, or SITS, and 5-HT was applied about $30 \mathrm{sec}$ later. The cell was superfused with drug-free solution, and a control 5-HT pulse was applied between each drug test. $B$, Retzius cell was voltage-clamped at $-90 \mathrm{mV}$ and was superfused with $\mathrm{Na}+\mathrm{K} \mathrm{SO}_{4}$ solutions (containing $100 \mu \mathrm{M}$ 9-AC) without CYP (control: first and third traces) or with $100 \mu \mathrm{M}$ CYP present (second trace), and 5-HT was applied as described above. The current traces were superimposed at the beginning of the recordings.

5-HT rendered the $\mathrm{P}$ cell insensitive to 5-HT application when tested in TrisCl solution. This was likely due to desensitization of $\mathrm{gCl}_{\mathrm{S}}$ (Henderson, 1983). However, incubation with 5-HT did not affect the magnitude of $g$ Cation $_{\mathrm{s}}$ Thus, incubation of a single $P$ cell with 5-HT resulted in the opposite effect of synapse formation: reduction of $g \mathrm{Cl}_{\mathrm{s}}$ without the loss of $g \mathrm{Cation}_{\mathrm{s}}$.

Pairs of juxtaposed cells were cultured in the presence of reserpine in order to deplete the Retzius cells of 5-HT. Following $7-10 \mathrm{~d}$ incubation in the presence of $1 \mu \mathrm{M}$ reserpine, the cells retained normal resting potentials and action potential waveforms (not shown). In contrast to untreated Retzius cells, we did not observe connections between these neurons and the $P$ cell, nor did the Retzius cells fluoresce when stained with a 5-HT-specific monoclonal antibody (Fig. 5), presumably due to depletion of 5-HT. The P cells of these reserpine-treated pairs had a $g \mathrm{Cl}_{\mathrm{S}}$ and a $g$ Cation $_{\mathrm{S}}$ similar to that of untreated pairs (lower stippled bars, Fig. 4). Thus, the depletion of presynaptic transmitter failed to prevent the reduction of gCation $_{s}$

\section{Effects of fixed Retzius cells}

Single P cclls plated ncar (10-50 $\mu \mathrm{m}$ away from) but not in contact with Retzius cells had normal magnitudes of both $\mathrm{gCl}_{\mathrm{S}}$ ad $g$ Cation ${ }_{\mathrm{s}}$, even when a second $\mathrm{P}$ cell contacted the Retzius cell and had a reduced $g$ Cation $_{\mathrm{S}}$ (not shown). This suggests that intimate contact between the cells was required for the loss of $g$ Cation $_{\mathrm{S}}$ rather than the secretion of a factor other than transmitter. In order to demonstrate this directly, we examined the effects of pairing (untreated) P cells with aldehyde-fixed Retzius cells since the latter would be incapable of secreting.

In preliminary experiments, $\mathrm{P}$ cells were paired with Retzius cells that had been fixed using the same concentration of aldehydes as in our previous study of membrane recycling during exocytosis at the Retzius-P cell synapse in culture (Kuffer et al., 1987; see Materials and Methods). The fixed Retzius cells adhered less well than did untreated neurons to the $P$ cells during plating. Furthermore, both $g \mathrm{Cl}_{\mathrm{S}}$ and $g \mathrm{Cation}_{\mathrm{S}}$ were greatly reduced in the P cells $\left(g \mathrm{Cl}_{\mathrm{s}}: 2.9 \pm 5.0 \mathrm{nS}, n=7 ;\right.$ CCation $_{\mathrm{s}}: 0.1$ $\pm 0.5 \mathrm{nS}, n=8$ ). These observations rule out a role for secretion of a factor (other than transmitter) by the Retzius cell since otherwise the fixed Retzius cells should have been ineffective. However, the poor adhesion of the Retzius cells and the nonselective loss of both responses to 5-HT suggest an effect of the fixative on the Retzius cell surface at high aldehyde concentrations. We therefore tested the effects of Retzius cells fixed in dilute aldehyde solutions.

At a 100-fold dilution of the fixative concentration, the Retzius cells were killed but were not fixed since the cells decomposed after a few days in culture. Following fixation at 10- or 30-fold dilutions of the fixative (pooled data), the Retzius cells lacked resting and action potentials and failed to retract the initial axon segment retained following dissection, contrary to what is observed with untreated cells after being plated overnight (Dietzel et al., 1986). In addition, these Retzius cells adhered properly to the P cells. In contrast to the Retzius cells, the paired (untreated) $P$ cells retained normal resting and action potentials (not shown), demonstrating that the fixative had been effectively removed from the Retzius cells. We therefore tested the effects of Retzius cells fixed at these lower aldehyde concentrations on the responses to 5-HT in the P cells to which they were coupled.

$\mathrm{gCl}_{\mathrm{S}}$ was insignificantly lower in the $\mathrm{P}$ cells (cross-hatched bar, Fig. 4A) compared with the level observed with untreated paired (uninnervated) neurons. In contrast, $P$ cells coupled with fixed Retzius cells had as low a level of $g$ Cation (cross-hatched bar, Fig. $4 B$ ) as in $\mathrm{P}$ cells paired with untreated Retzius cells. We conclude that fixed Retzius cells retained the ability to induce the selective loss of postsynaptic gCation ${ }_{\mathrm{S}}$ due to contact between the neurons.

\section{Discussion}

Upon innervation of a $\mathrm{P}$ cell by a Retzius cell in culture, application of 5-HT resulted in a reduced $g \mathrm{Cl}_{\mathrm{s}}$. This has been accounted for as the result of a high density of synaptic receptors and a synaptic diffusional barrier to applied 5-HT (Drapeau and Sanchez-Armass, 1988). The lowering of $\mathrm{gCl}_{\mathrm{s}}$ in the presynaptic Retzius cell indicates that both neurons responded to synapse formation. In contrast to the observations with $\mathrm{gCl}_{\mathrm{S}}$, $g$ Cation ${ }_{\mathrm{S}}$ was lowered selectively in the postsynaptic $\mathrm{P}$ cell during reinnervation. Taken together, the results with $\mathrm{P}$ cells incubated in 5-HT or paired with 5-HT-depleted or with fixed Retzius cells demonstrated that contact (rather than secretion) was responsible for the reduction of $g$ Cation $_{\mathrm{s}}$ in the $\mathrm{P}$ cell.

The detailed information obtained from studies of $\mathrm{ACh}$ receptor clustering at the neuromuscular junction offers an inter- 
A

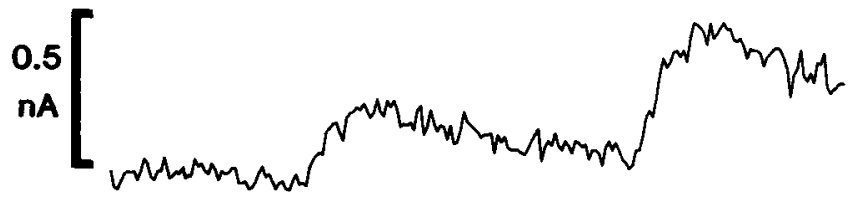

B

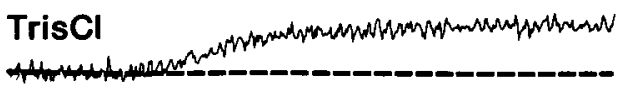

P cell
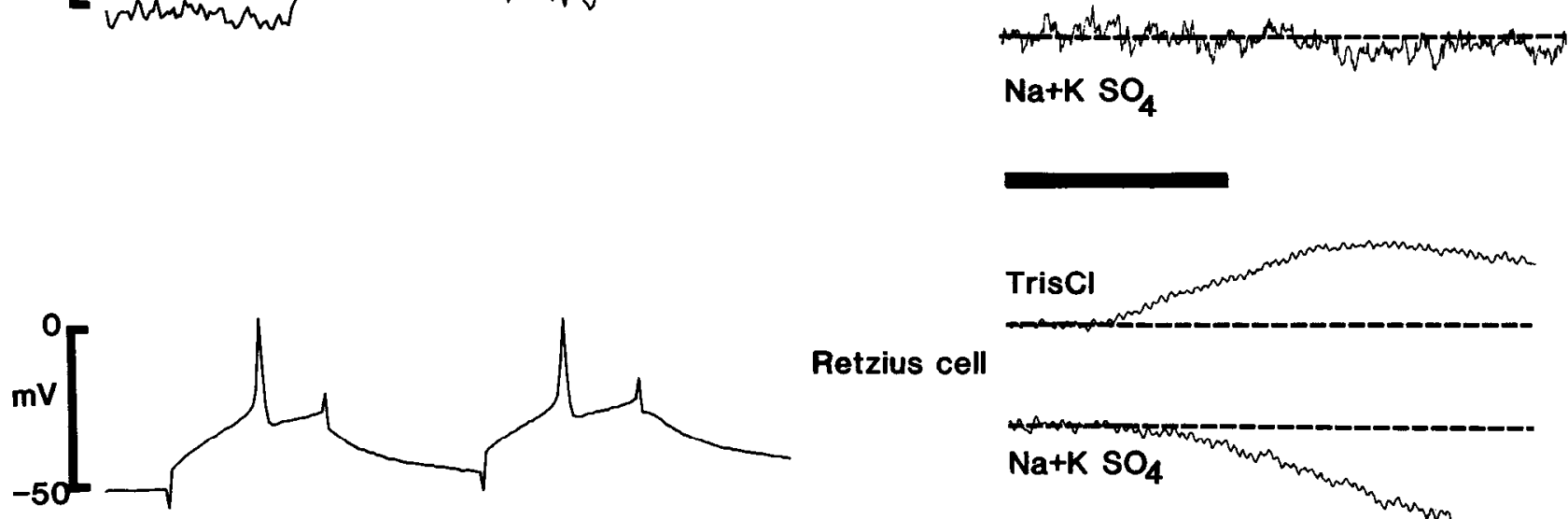

Retzius cell
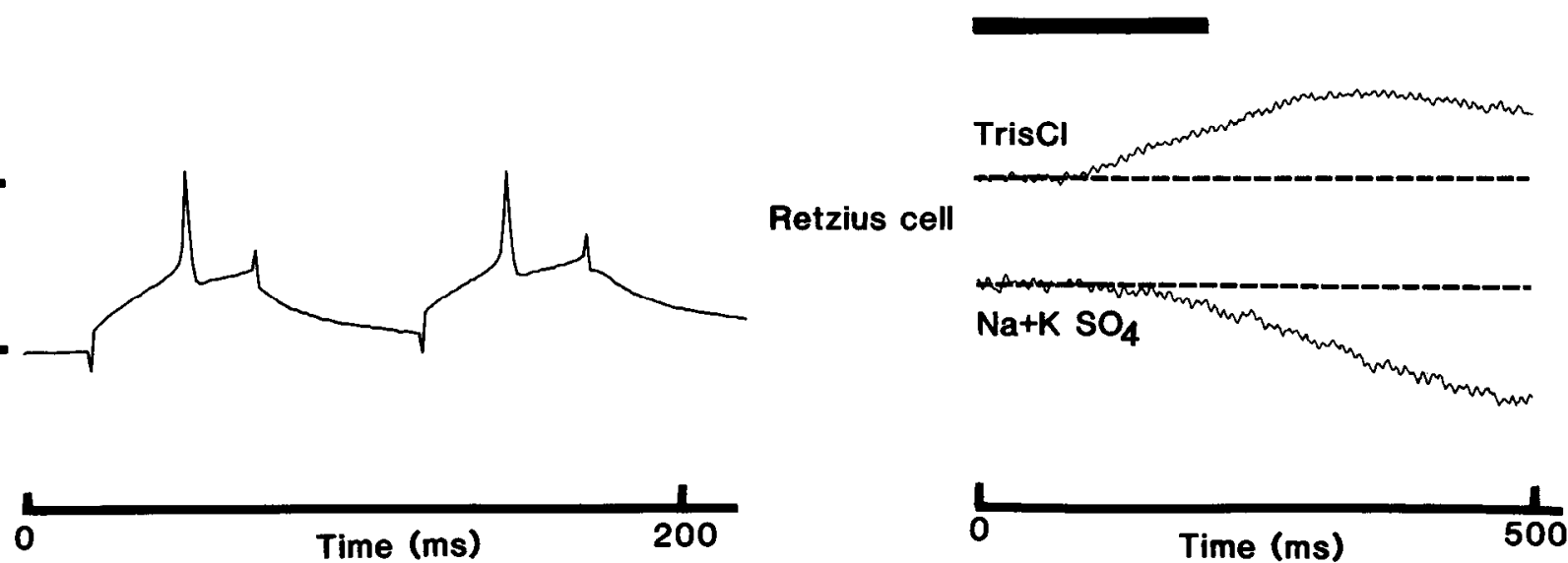

Figure 3. $g \mathrm{Cl}_{\mathrm{S}}$ and $g \mathrm{Cation}_{\mathrm{s}}$ in the cultured Retzius cell and innervated $\mathrm{P}$ cell. $A$, Action potentials were evoked in a Retzius cell, and synaptic currents were recorded in the $P$ cell at a holding potential of $-20 \mathrm{mV}$. B, Recordings of the currents activated by 5-HT application from a pipette onto the innervated $\mathrm{P}$ cell (topmost pair of traces) superfused in TrisCl solution (upper of these traces) and $\mathrm{Na}^{2} \mathrm{~K} \mathrm{SO}_{4}$ solution (lower of these traces). The lowermost pair of recordings were obtained while applying 5-HT onto the presynaptic Retzius cell superfused in TrisCl solution (upper of these traces) and $\mathrm{Na}+\mathrm{K} \mathrm{SO}_{4}$ solution (lower of these traces). The cells were voltage-clamped at $-20 \mathrm{mV}$ (TrisCl traces) or at $-70 \mathrm{mV}$ ( $\mathrm{Na}+K$ $\mathrm{SO}_{4}$ traces), and the baseline currents are indicated by the broken lines.

esting correlate to our observations with 5-HT responses. In their elegant study of embryonic Xenopus spinal cord neurons and muscle cells in culture, Cohen et al. (1987) determined that it is at the sites of contact between the cells that the first signs of synapse formation are apparent. At these sites, they observed the appearance of neuron-associated receptor patches in the muscle cells and saw synaptic vesicle antigen patches in the neurons. Although both trophic factors and cell contact have
A

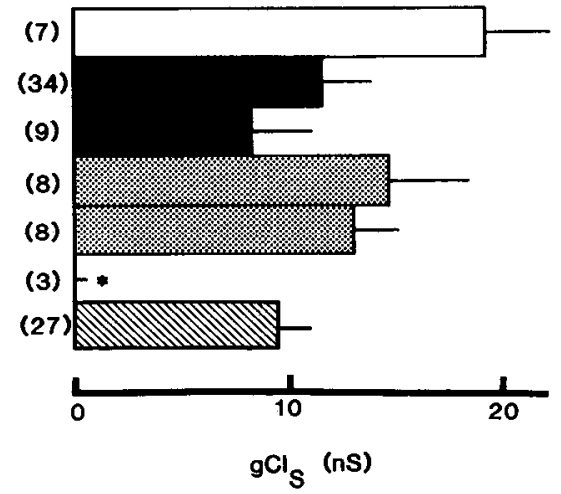

B

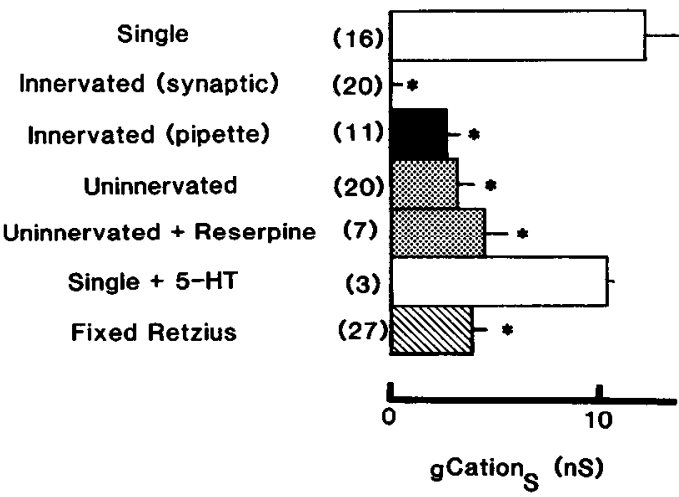

Figure 4. Summary of $\mathrm{gCl}_{\mathrm{s}}$ and $g$ Cation $\mathrm{s}$ in $\mathrm{P}$ cells cultured under a variety of conditions. $A$, Histogram shows the pooled results of measurements of $g_{\mathrm{Cl}}$. $B$, Histogram shows the results for $g$ Cation in $_{\mathrm{P}} \mathrm{P}$ cells. The upper open hars are the results for single $\mathbf{P}$ cells and the filled bars are the results for innervated P cells when 5-HT was released synaptically (upper filled bars) and from a pipette (lower filled bars) (from Fig. 12, Drapeau and Sanchez-Armass, 1988). The stippled bars are the results for $\mathrm{P}$ cells paired with but not innervated by (Uninnervated) a Retzius cell (upper stippled bars) and for $\mathrm{P}$ cells paired with a Retzius cell and incubated for 7-10 d in medium containing $1 \mu \mathrm{M}$ reserpine (lower stippled bars). The lowermost open bars are the results for single P cells incubated 7-10 d in medium containing $100 \mu \mathrm{M}$ 5-HT (present throughout the period of incubation, see Materials and Methods). The cross-hatched bars at the bottom are the results for $\mathrm{P}$ cells paired with aldehyde-fixed Retzius cells. The values in parentheses are the number of determinations. Asterisks indicate $p<0.01$ for the significance of the difference between the means (Student's $t$ test) of the indicated data and the corresponding control results with single P cells. 


\section{Control}

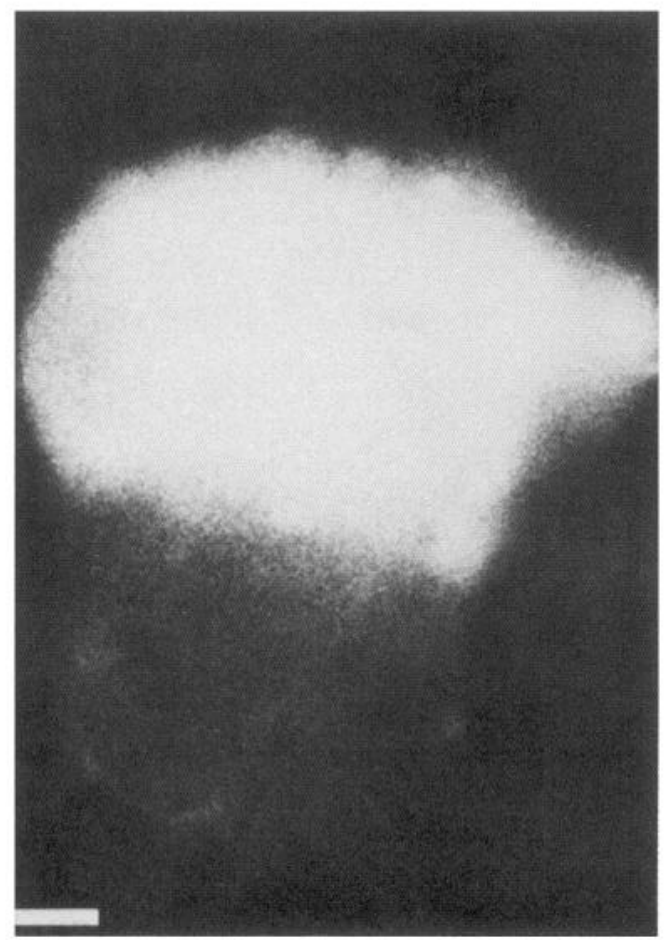

\section{+ Reserpine}

\section{Retzius cell}

\section{$P$ cell}

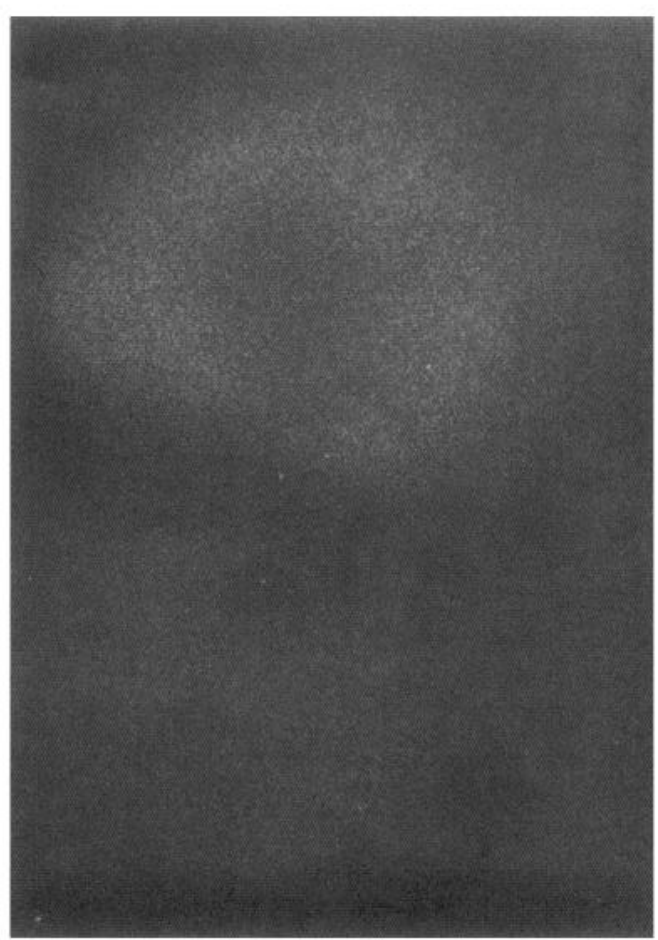

Figure 5. Effect of reserpine on the 5-HT content of cultured Retzius cells. The left-hand panel is a fluorescence micrograph of a Retzius-P cell pair (the upper cell is the Retzius cell) stained with a monoclonal antibody to 5-HT (see Materials and Methods). Scale bar, $10 \mu \mathrm{m}$. The right-hand panel shows a Retzius-P cell pair that had been incubated in $1 \mu \mathrm{M}$ reserpine for $7 \mathrm{~d}$ before staining with the antibody.

been implicated in $\mathrm{ACh}$ receptor clustering, the latter is more critical during development (Bloch and Pumplin, 1988).

The selective loss of $g$ Cation $_{s}$ in the postsynaptic P cell suggests a cell-specific effect of neuronal contact. Since cultured leech neurons lack an extracellular matrix (Kuffler et al., 1987), this would rule out the role of extracellular components of the type thought to be critical during regeneration of the neuromuscular junction (Godfrey et al., 1984). The loss of $g$ Cation $_{\mathrm{s}}$ in the $\mathrm{P}$ cell must therefore be mediated by a surface molecule in the Retzius cell, perhaps of the type believed to play an important role during the development of the nervous system (Schachner et al., 1983; Dodd and Jessell, 1986).

Surface molecules have generally been thought to mediate adhesive interactions during CNS development (Purves and Lichtman, 1985). All types of cultured leech neurons, in our experience, adhere not only to their targets but also to neurons they do not innervate. This is seen upon trying to remove a microelectrode from an impaled neuron, which is all too easily lifted off the dish along with its (unimpaled) partner, be it a target or not. Therefore, although adhesion is necessary for synapse formation, it appears to be insufficient for the recognition of targets. Other (perhaps subsequent) steps are required for neuronal recognition, an example of which is the contact-induced selection of transmitter receptor subtypes described in this report.

If a similar process underlies the selection of responses during synapse formation between Retzius and P cells in vivo, the loss of the countereffective (excitatory) response may be necessary before a functional (inhibitory) synapse can be formed. In cul- tures of nodose ganglion neurons from embryonic rats, nonneuronal satellite cells induce the loss of the neuronal response to ACh and prevent synapse formation (Cooper, 1984). A similar loss of receptors is thought to occur during the development of this ganglion in vivo (Cooper and Lau, 1987). The inductive redistribution of transmitter receptors at critical sites in target neurons with multiple receptor subtypes may therefore be an important step during the development of the nervous system. Since competition for synapse formation is important during development (Purves and Lichtman, 1985), the early clearing of countereffective postsynaptic receptors at sites of contact would ensure that newly formed synapses are immediately effective by permitting the activation of only the correct receptors.

Interestingly, the opposite phenomenon has also been observed in cultured neurons: embryonic chick spinal cord motor neurons only express a second type of glutamate receptor when cocultured with their presynaptic interneurons (O'Brien and Fischbach, 1986). Therefore, both the loss and induction of receptor subtypes may be important during neural development.

The responses to 5-HT in P cells are processed in parallel, being linked to the opening of distinct ionic channels mediated by separate second-messenger pathways coupled to the activation of different receptor subtypes (Drapeau and Sanchez-Armass, 1989). Thus, $\mathrm{gCl}_{\mathrm{s}}$ is dependent on cyclic AMP and protein kinase A and is insensitive to mammalian 5-HT receptor agonists and antagonists. In contrast, $g$ Cation $_{\mathrm{s}}$ has the pharmacological properties of $5-\mathrm{HT}_{2}$ receptors (e.g., selectively blocked by ketanserin) and is apparently mimicked by phorbol esters which activate protein kinase $C$. It will be of interest to 


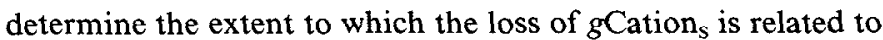
the loss of specific receptors, intracellular mediators, and numbers or activity of ionic channels. This model culture preparation should permit a more detailed characterization of the interactions underlying neuronal recognition during synaptogenesis.

\section{References}

Anderson, G., K. L. Teff, and S. N. Young (1987) Serotonin in cisternal cerebrospinal fluid of the rat: Measurement and use as an index of functionally active serotonin. Life Sci. 40: 2253-2260.

Bixby, J. L., and N. C. Spitzer (1982) The appearance and development of chemosensitivity in Rohon-Beard neurones of the Xenopus spinal cord. J. Physiol. (Lond.) 330: 513-536.

Bloch, R. J., and D. W. Pumplin (1988) Molecular events in synaptogenesis: Nerve-muscle adhesion and postsynaptic differentiation. Am. J. Physiol. 254 (Cell Physiol. 23): C345-C364.

Bryant, S. H., and A. Morales-Aguilera (1971) Chloride conductance in normal and myotonic muscle fibres and the action of monocarboxylic aromatic acids. J. Physiol. (Lond.) 219: 367-383.

Cohen, M. W., E. Rodriguez-Marin, and E. M. Wilson (1987) Distribution of synaptic specializations along isolated motor units formed in Xenopus nervc-muscle culturcs. J. Neurosci. 7: 2849-2861.

Consolazione, A., C. Milstein, B. Wright, and A. C. Cuello (1981) Immunocytochemical detection of serotonin with monoclonal antibodies. J. Histochem. Cytochem. 29: 1425-1430.

Cooper, E. (1984) Synapse formation among developing sensory neurones from rat nodose ganglia grown in tissue culture. J. Physiol. (Lond.) 351: 263-274.

Cooper, E., and M. Lau (1987) Factors affecting the expression of acetylcholine receptors on rat sensory neurones in culture. J. Physiol. (Lond.) 377: 409-420.

Dietzel, I. D., P. Drapeau, and J. G. Nicholls (1986) Voltage dependence of 5-hydroxytryptamine release at a synapse between identified leech neurones in culture. J. Physiol. (Lond.) 372: 191-205.

Dodd, J., and T. M. Jessell (1986) Cell surface glycoconjugates and carbohydrate-binding proteins: Possible recognition signals in sensory neuron development. J. Exp. Biol. 124: 225-238.

Drapeau, P., and S. Sanchez-Armass (1987) Selective loss of nonsynaptic and clustering of synaptic 5-HT receptors during innervation of an identified leech neuron in culture. Soc. Neurosci. Abstr. 13: 1423.

Drapeau, P., and S. Sanchez-Armass (1988) Selection of postsynaptic serotonin receptors during reinnervation of an identified leech neuron in culture. J. Neurosci. 8: 4718-4727.

Drapeau, P., and S. Sanchez-Armass (1989) Parallel processing and selection of the responses to serotonin during reinnervation of an identified leech neuron. J. Neurobiol. (in press).

Erwin, D. E., and R. E. Theis (1975) Effect of neuraminidase + ethylene-diaminetetraacetic acid (EDTA) upon the serotonin receptors of Retzius cells in the leech. Fed. Proc. 34: 359.

Fambrough, D. M. (1979) Control of acetylcholine receptors in skeletal muscle. Physiol. Rev. 59: 165-227.

Fuchs, P. A., J. G. Nicholls, and D. F. Ready (1981) Membrane properties and selective connexions of identified leech neurones in culture. J. Physiol. (Lond.) 316: 203-223.

Fuchs, P. A., L. P. Henderson, and J. G. Nicholls (1982) Chemical transmission between individual Retzius and sensory neurones of the leech in culture. J. Physiol. (Lond.) 323: 195-210.

Gerschenfeld, H. M. (1973) Chemical transmission in invertebrate central nervous systems and neuromuscular junctions. Physiol. Rev. 53: $1-119$.

Gerschenfeld, H. M., and D. Paupardin-Tritsch (1974) On the transmitter function of 5-hydroxytryptamine at excitatory and inhibitory monosynaptic junctions. J. Physiol. (Lond.) 243: 457-481.

Godfrey, E. W., R. M. Nitkin, B. G. Wallace, L. L. Rubin, and U. J. McMahan (1984) Components of Torpedo electric organ and muscle that cause aggregation of acetylcholine receptors on cultured muscle cells. J. Cell Biol. 99: 614-627.

Goodman, C. S., and N. C. Spitzer (1979) Embryonic development of identified neurons: Differentiation from neuroblast to neuron. Nature 280: 208-214.

Henderson, L. P. (1983) The role of 5-hydroxytryptamine as a transmitter between identified leech neurones in culture. J. Physiol. (Lond.) 339: 309-324.

Katz, B., and R. Miledi (1972) The statistical nature of the acetylcholine potential and its molecular components. J. Physiol. (Lond.) 224: 665-699.

Knauf, P. A., and A. J. Rothstein (1971) Chemical modification of membranes. 1. Effects of sulfhydryl and amino reactive reagents on anion and cation permeability of the human red blood cell. J. Gen. Physiol. 58: 190-210.

Kuffler, D. P., J. G. Nicholls, and P. Drapeau (1987) Transmitter localization and vesicle turnover at a serotoninergic synapse between identified leech neurons in culture. J. Comp. Neurol. 256: 516-526.

Mishina, M., T. Takai, K. Imoto, M. Noda, T. Takahashi, S. Numa, C. Methfessel, and B. Sakmann (1986) Molecular distinction between fetal and adult forms of muscle acetylcholine receptor. Nature 321: 406-411.

Neher, E., and B. Sakmann (1976) Noise analysis of drug induced voltage clamp currents in denervated frog muscle fibers. J. Physiol. (Lond.) 258: 705-729.

Nicholls, J. G. (1987) The search for connections: Studies of regeneration in the nervous system of the leech. In Magnes Lecture Series, Vol. 2, pp. 1-86.

O'Brien, R. J., and G. D. Fischbach (1986) Modulation of embryonic chick motorneuron glutamate sensitivity by interneurons and agonists. J. Neurosci. 6: 3290-3296.

Purves, D., and J. W. Lichtman (1985) Principles of Neural Development, Sinauer, Sunderland, MA.

Ready, D. F., and J. G. Nicholls (1979) Identified neurons isolated from leech CNS make selective connections in culture. Nature 281 : 67-68.

Sanchez-Armass, S., and P. Drapeau (1988) Modification of transmitter receptor properties mediated by cell contact prior to synapse formation. Soc. Neurosci. Abstr. 14: 178.

Sawada, M., and R. E. Coggeshall (1976) Ionic mechanism of 5-hydroxytryptamine induced hyperpolarization and inhibitory junctional potential in body wall muscle cells of Hirudo medicinalis. J. Neurobiol. 7: 63-73.

Schachner, M., A. Faissner, J. Kruse, J. Lindner, D. H. Meier, E. G. Rathjen, and H. Wernecke (1983) Cell-type specificity and developmental expression of neural cell-surface components involved in cell interactions and of structurally related molecules. Cold Spring Harbor Symp. Quant. Biol. 48: 557-568.

Walker, R. J., and P. A. Smith (1973) The ionic mechanism for 5-hydroxytryptamine inhibition of Retrius cells of the leech Hirudo medicinalis. Comp. Biochem. Physiol. 45A: 979-993. 